\title{
Staphylococcus aureus RNAIII coordinately represses the synthesis of virulence factors and the transcription regulator Rot by an antisense mechanism
}

\author{
Sandrine Boisset, ${ }^{1,5}$ Thomas Geissmann, ${ }^{2,5}$ Eric Huntzinger, ${ }^{2,5}$ Pierre Fechter, ${ }^{2}$ Nadia Bendridi, ${ }^{1}$ \\ Maria Possedko, ${ }^{2}$ Clément Chevalier ${ }^{2}$, Anne Catherine Helfer, ${ }^{2}$ Yvonne Benito, ${ }^{1}$ Alain Jacquier, ${ }^{3}$ \\ Christine Gaspin, ${ }^{4}$ François Vandenesch, ${ }^{1}$ and Pascale Romby ${ }^{2,6}$ \\ ${ }^{1}$ Institut National pour la Recherche Médicale (INSERM) E0230, Université Lyon 1, Centre National de Référence des \\ Staphylocoques, Faculté Laennec, Lyon, F-69008, France; ${ }^{2}$ Architecture et Réactivité de l'ARN, Université Louis Pasteur, \\ Centre National de la Recherche Scientifique (CNRS), Institut de Biologie Moléculaire et Cellulaire (IBMC), F-67084 \\ Strasbourg, France; ${ }^{3}$ Unité de Génétique des Interactions Macromoléculaires, URA 2171-Centre National de la Recherche \\ Scientifique, Institut Pasteur, F-75724 Paris, France; ${ }^{4}$ Unité de Biométrie et Intelligence Artificielle, Institut de National de \\ la Recherche Agronomique (INRA)-UR875 Chemin de Borde-Rouge, F-31326 Castanet-Tolosan, France
}

\begin{abstract}
RNAIII is the intracellular effector of the quorum-sensing system in Staphylococcus aureus. It is one of the largest regulatory RNAs (514 nucleotides long) that are known to control the expression of a large number of virulence genes. Here, we show that the 3' domain of RNAIII coordinately represses at the post-transcriptional level, the expression of mRNAs that encode a class of virulence factors that act early in the infection process. We demonstrate that the $3^{\prime}$ domain acts primarily as an antisense RNA and rapidly anneals to these mRNAs, forming long RNA duplexes. The interaction between RNAIII and the mRNAs results in repression of translation initiation and triggers endoribonuclease III hydrolysis. These processes are followed by rapid depletion of the mRNA pool. In addition, we show that RNAIII and its $3^{\prime}$ domain mediate translational repression of rot mRNA through a limited number of base pairings involving two loop-loop interactions. Since Rot is a transcriptional regulatory protein, we proposed that RNAIII indirectly acts on many downstream genes, resulting in the activation of the synthesis of several exoproteins. These data emphasize the multitude of regulatory steps affected by RNAIII and its 3' domain in establishing a network of $S$. aureus virulence factors.
\end{abstract}

[Keywords: Regulatory RNA; translational repression; antisense regulation; RNase III; virulence; Staphylococcus aureus]

Supplemental material is available at http://www.genesdev.org.

Received December 22, 2006; revised version accepted April 5, 2007.

The ability of organisms to use RNA to modulate gene expression is a relatively new concept. In bacteria, antisense RNA regulates essential functions in extrachromosomal elements (Wagner et al. 2002). Novel small RNAs (sRNAs) were discovered mainly in Escherichia coli that are a part of regulatory networks required for fast adaptive response to stress and environmental changes (Gottesman 2005; Storz et al. 2005). Functional studies revealed that many of the sRNAs act as antisense RNAs on mRNAs that encode for outer membrane proteins in $E$. coli and Salmonella typhymurium. This suggests that

\footnotetext{
${ }^{5}$ These authors contributed equally to this work. ${ }^{6}$ Corresponding author.

E-MAIL P.Romby@ibmc.u-strasbg.fr. FAX: 33-388602218.

Article is online at http://www.genesdev.org/cgi/doi/10.1101/gad.423507.
}

sRNAs modulate the surface composition of Gram-negative bacteria (for review, see Guillier et al. 2006; Vogel and Papenfort 2006). Novel sRNAs have also been identified in Gram-positive pathogens such as Staphylococcus aureus (Pichon and Felden 2005; Roberts et al. 2006) and Listeria monocytogenes (Mandin et al. 2007). Several $S$. aureus sRNAs are encoded by pathogenicity islands (Pichon and Felden 2005); some of the Listeria sRNAs are unique to the pathogenic species (Mandin et al. 2007).

These observations suggest that RNA-RNA interactions would be decisive for virulence regulation or for adaptive stress responses needed for the survival in a host. This has been shown for the largest regulatory RNA, S. aureus RNAIII (514 nucleotides [nt] long), which controls the switch between the expression of sur- 
Boisset et al.

face proteins and excreted toxins (Novick et al. 1993). The expression of RNAIII is induced by the agr system, which functions as a sensor of the population density. While RNAIII is not essential for $S$. aureus growth in vitro, several studies have shown its importance for virulence in animal models (Cheung et al. 1994; Gillaspy et al. 1995). Nearly all S. aureus clinical isolates from acute infections have been shown to produce RNAIII. This RNA has a small ORF near the $5^{\prime}$ end that encodes for the $\partial$-hemolysin, and the noncoding regions are suspected to have regulatory functions (Novick 2003). The structure of RNAIII is characterized by 14 stem-loop motifs and two long-distance interactions that define independent structural domains (Benito et al. 2000). Among the conserved domains, three of the hairpin motifs contain C-rich sequences in their apical loops (Fig. 1A) that could potentially base-pair with the Shine and Dalgarno (SD) sequences of target mRNA (Benito et al. 2000; Novick 2003). Two direct mRNA targets of RNAIII have been identified so far, both of them encoding virulence factors. These studies revealed that RNAIII uses structural domains to act as an antisense RNA for hla ( $\alpha$-hemolysin) mRNA translational activation (Morfeldt et al. 1995) and for repression of the synthesis of the main surface adhesin protein A (Huntzinger et al. 2005). In the latter case, the $3^{\prime}$-end domain, in particular stemloop 13, binds to the ribosome-binding site (RBS) of the spa mRNA, preventing ribosome binding and inducing rapid $\mathrm{mRNA}$ degradation initiated by the double-strandspecific endoribonuclease III (RNase III). RNAIII is thus an example of a multiple target regulator, which modulates the expression of genes involved in pathogenesis. It is likely that RNAIII may also indirectly control virulence gene expression by targeting regulatory proteins that account for the regulation of many downstream genes (Dunman et al. 2001; Novick 2003). Similarly, S. aureus has evolved a plethora of sensory systems that turn on/off the expression of virulence genes in response to both environmental and host signals. A complex regulatory network involves interplay between several twocomponent systems and transcriptional regulatory proteins from the Sar family (SarS, SarT, Rot, SarA) (Novick

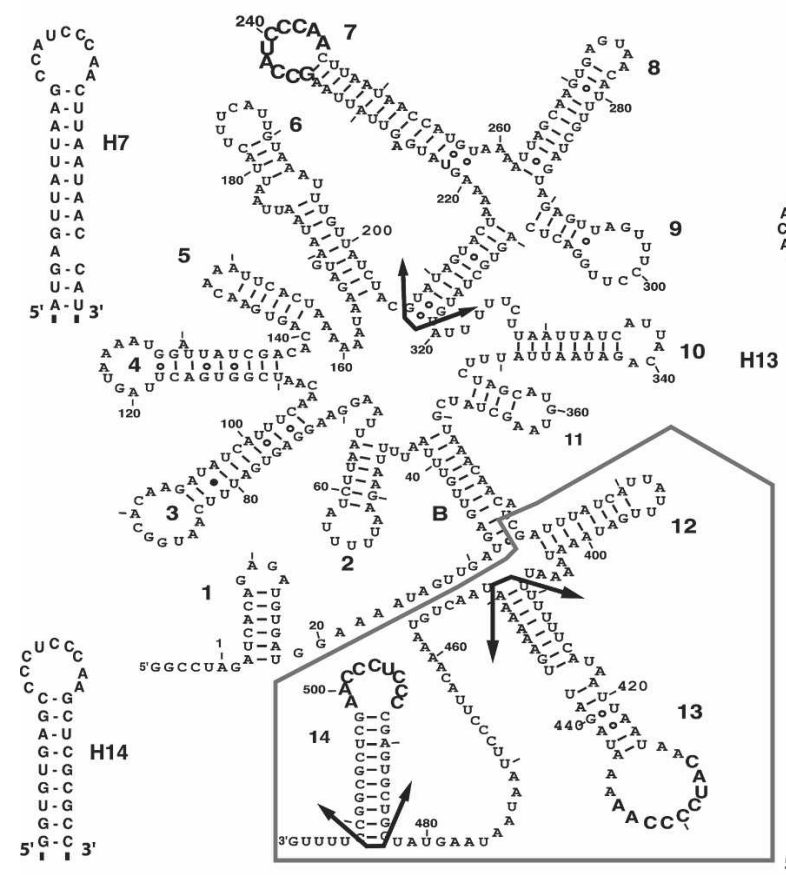

A

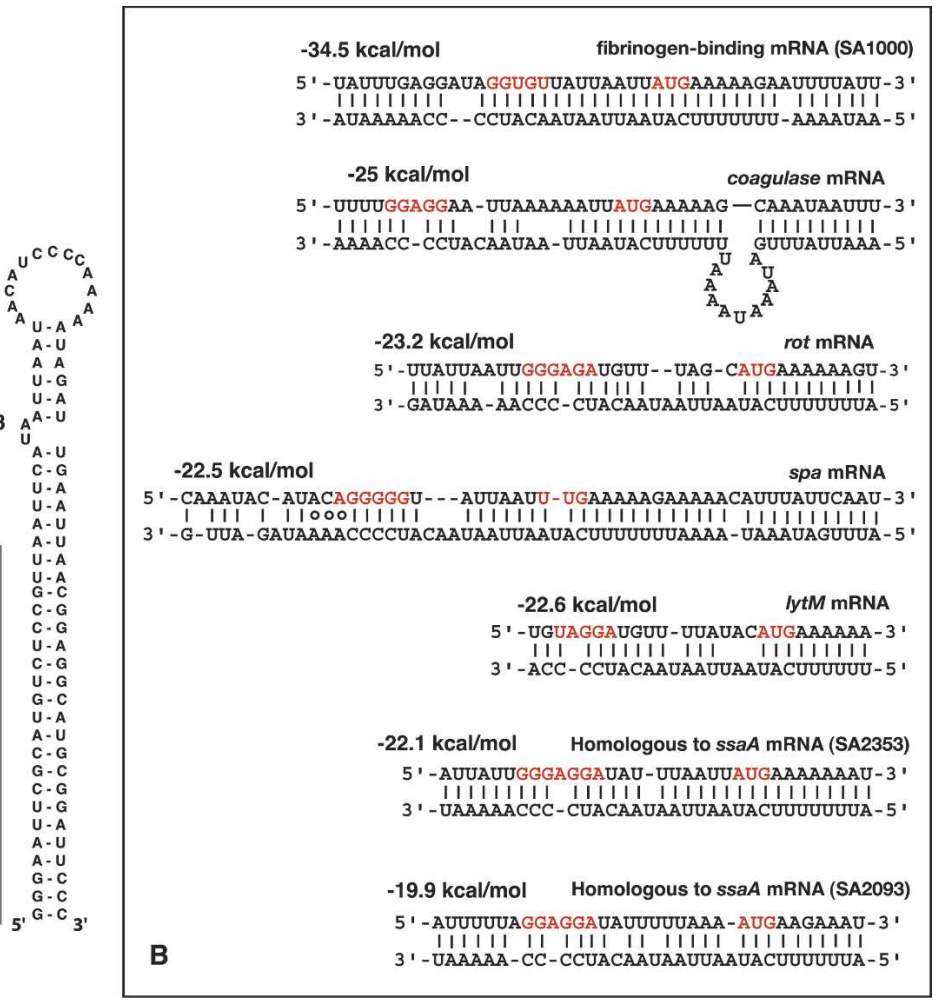

Figure 1. Secondary structure of RNAIII and potential base pairings with target mRNAs. $(A)$ The secondary structure of RNAIII is from Benito et al. (2000). Deletion of the central domain (RNAIII- $\Delta 7-9$ ), of hairpin 13 (RNAIII- $\Delta 13$ ) or of hairpin 14 (RNAIII- $\Delta 14$ ) is delimitated by arrows. The isolated hairpins H7, H13, and H14 used in this work are shown. The first 19 bp of H13 are also present in $\mathrm{H} 14$ and H7. (B) Potential base pairings between the hairpin 13 and mRNAs encoding for virulence factors and for the transcriptional regulatory protein Rot. The minimum free energy for each sequence is given. The levels of several mRNAs were shown to be growth-phase dependent and were strongly decreased as soon as RNAIII was synthesized: spa (Huntzinger et al. 2005), coa (Lebeau et al. 1994), lytM (Ramadurai et al. 1999), SA1000 and SA2353 (this study). The synthesis of Rot is regulated at the translational level by RNAIII (Geisinger et al. 2006; this study). The mRNAs encoding protein A and SA2093 were also not detected in a mutant strain deleted of the agr operon that does not express RNAIII (Dunman et al. 2001). The SD sequences and the AUG codons are indicated in red. The hybrids formed between RNAIII and spa mRNA or SA1000 mRNA were analyzed by chemical and enzymatic probing, Noncanonical base pairs are denoted by circles in these duplexes. 
2003). Among these pleiotropic transcription factors, Rot (for repressor of toxins) has been identified as a general antagonist of agr regulation. Since transcription of rot is constitutive, it was proposed that RNAIII regulates the activity of Rot by sequestrating the protein (Said-Salim et al. 2003; Oscarsson et al. 2005). More recently, it was shown that the RNAIII-dependent regulation of Rot occurs at the translational level (Geisinger et al. 2006).

We show here that the 3 '-end domain of RNAIII represses the synthesis of several surface and secreted proteins specific to $S$. aureus, using a shared antisense regulatory mechanism. This domain uses two redundant hairpin loop motifs to target rot mRNA. In all these systems, the formation of RNAIII-mRNA duplexes leads to the inhibition of ribosome binding and favors specific recognition by RNase III. A proteomic analysis also reveals that the $3^{\prime}$ domain by itself is sufficient to promote the synthesis of several exoproteases and exotoxins. This multiregulatory domain of RNAIII acts directly on the expression of a class of virulence factors and indirectly via the translational regulation of a pleiotropic regulatory protein.

\section{Results}

\section{Identification of potential mRNA targets of RNAIII}

Many sRNAs act as antisense RNAs by interacting with mRNAs (for review, see Storz et al. 2005). While only a small number of targets have been experimentally identified for a given sRNA, it is expected that many of them regulate more than one mRNA transcript. We hypothesized that the highly conserved $3^{\prime}$ domain of RNAIII targets the RBS of other mRNAs in a manner similar to spa mRNA. Thus, the strategy used here to predict mRNA targets is based on base pairing between the RBS of mRNAs and the stem-loop 13 of RNAIII. The sequence of each RBS of all mRNAs was concatenated to

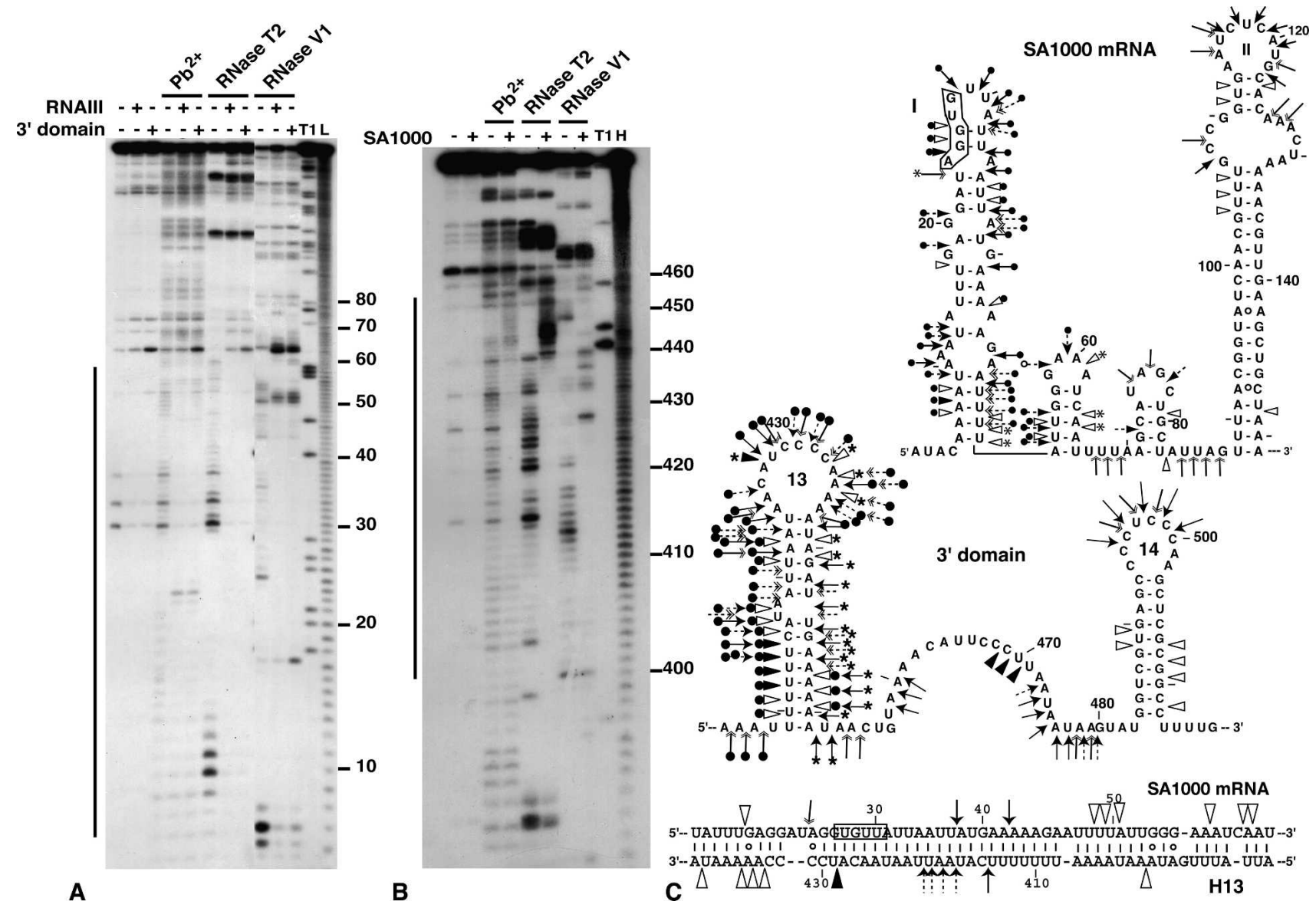

Figure 2. RNAIII and its $3^{\prime}$ domain bind to the RBS of SA1000 mRNA. $(A, B)$ Enzymatic hydrolysis (RNases T2 and V1) and lead-induced cleavages $\left(\mathrm{Pb}^{2+}\right)$ of $5^{\prime}$-end-labeled SA1000 mRNA free $(-)$ or with a twofold excess of RNAIII $(+)(A)$ or 5'-end-labeled 3' domain free (-) or with a twofold excess of SA1000 mRNA (+) (B). (Lane T1) RNase T1. (Lane L) Alkaline ladders. Bars denote the main reactivity changes induced by complex formation. $(C)$ Probing data represented on the secondary structure of SA1000 mRNA-the 3' domain of RNAIII and of the RNAIII-SA1000 mRNA duplex. Enzymatic cleavages are as follows: RNase T1 $(\rightarrow)$, RNase T2 $(\rightarrow)$ lead cleavages $(\rightarrow)$, and RNase V1 moderate $(\triangleright)$ and strong $(-)$ cleavages. Reactivity changes induced by complex formation are indicated as follows: Black or empty circles indicate strong and moderate protection, respectively; enhancements are shown by asterisks; and new RNase V1 cleavages are denoted by arrows followed by an asterisk. For RNAIII-SA1000 duplex, the same symbols for lead cleavage and RNase V1, and RNase III $(\rightarrow)$ are used. The SD sequence is squared on SA1000 mRNA. 
Boisset et al.

Table 1. Strains and plasmids

\begin{tabular}{|c|c|c|}
\hline E. coli strains & Relevant characteristics & Reference/source \\
\hline LUG1105 & BL21/pLUG693 & This study \\
\hline \multicolumn{3}{|l|}{ S. aureus strains } \\
\hline RN4220 & Restriction- mutant of $8325-4$ & Kreiswirth et al. 1983 \\
\hline RN6390 & Derivative of $8325-4$, agr positive & Peng et al. 1988 \\
\hline WA400 & 8325-4: $\Delta$ rnaIII region ::cat86 & Janzon and Arvidson 1990 \\
\hline LUG404 & WA400/pLUG274 & This study \\
\hline LUG450 & WA400/pLUG300 & Benito et al. 2000 \\
\hline LUG453 & WA400/pLUG304 & Huntzinger et al. 2005 \\
\hline LUG484 & WA400/pLUG324 & Huntzinger et al. 2005 \\
\hline LUG581 & WA400/pLUG298 & Huntzinger et al. 2005 \\
\hline LUG600 & WA400/pLUG389 & This study \\
\hline LUG774 & RN6390: $\Delta r n c$ region : cat86 & Huntzinger et al. (2005) \\
\hline LUG911 & RN6390: $\Delta h f q$ region $::$ cat 86 & This study \\
\hline LUG931 & RN6390/pLUG543 & This study \\
\hline LUG932 & LUG774/pLUG543 & This study \\
\hline LUG933 & WA400/pLUG543 & This study \\
\hline LUG935 & LUG581/pLUG543 & This study \\
\hline LUG936 & LUG450/pLUG543 & This study \\
\hline LUG1122 & LUG453/pLUG543 & This study \\
\hline LUG1123 & LUG600/pLUG543 & This study \\
\hline LUG1133 & LUG404/pLUG543 & This study \\
\hline LUG1141 & RN6390/pLUG550 & This study \\
\hline LUG1189 & WA400/pLUG661 & This study \\
\hline LUG1190 & WA400/pLUG667 & This study \\
\hline LUG1195 & RN6390/pLUG653 & This study \\
\hline LUG1196 & LUG774/pLUG653 & This study \\
\hline LUG1197 & WA400/pLUG653 & This study \\
\hline LUG1203 & LUG1189/pLUG653 & This study \\
\hline LUG1204 & LUG1190/pLUG653 & This study \\
\hline LUG1216 & LUG404/pLUG653 & This study \\
\hline LUG1217 & LUG450/pLUG653 & This study \\
\hline LUG1220 & LUG581/pLUG653 & This study \\
\hline LUG1221 & LUG600/pLUG653 & This study \\
\hline \multicolumn{3}{|l|}{ E. coli plasmid } \\
\hline pLUG693 & pET43::SA1000 (nucleotides 88-327) & This study \\
\hline pUT7-RNAIII & T7 promoter/RNAIII & Benito et al. 2000 \\
\hline pUT7-RNAIII $\Delta 7-9$ & $\begin{array}{l}\text { T7 promoter/RNAIII } \Delta \text { 7-9 (deletion of nucleotides } \\
207-320 \text { ) }\end{array}$ & This study \\
\hline pUT7-RNAIII $\Delta 13$ & $\begin{array}{l}\text { T7 promoter/RNAIII } \Delta 13 \text { (deletion of nucleotides } \\
408-451 \text { ) }\end{array}$ & Huntzinger et al. 2005 \\
\hline pUT7-RNAIII $\Delta 14$ & $\begin{array}{l}\text { T7 promoter/RNAIII } \Delta 14 \text { (deletion of nucleotides } \\
483-511 \text { ) }\end{array}$ & This study \\
\hline pUT7-SA1000 & $\begin{array}{l}\text { T7 promoter/SA } 1000 \text { (nucleotides }-37 \text { to }+200,+1 \text { being } \\
\text { the A of AUG codon) }\end{array}$ & This study \\
\hline pUT7-SA2353 & $\mathrm{T} 7$ promoter/SA2353 (nucleotides -126 to +117 ) & This study \\
\hline pUT7-rot & $\mathrm{T} 7$ promoter/rot (nucleotides -245 to +59 ) & This study \\
\hline \multicolumn{3}{|c|}{$\begin{array}{l}\text { E. coli-staphylococcal shuttle } \\
\text { plasmids }\end{array}$} \\
\hline pTCV-lac & $\begin{array}{l}\text { Promoter-lac fusion shuttle vector: spoVG-lacZ, ermB, } \\
\text { aphA-3 }\end{array}$ & Poyart and Trieu-Cuot 1997 \\
\hline pLUG220 & pTCV-lac $\Delta$ RBS and start codon & Huntzinger et al. 2005 \\
\hline pLUG533 & $\begin{array}{l}\text { pMAD derivative for deletion/replacement of } S \text {. aureus } \\
h f q \text { gene }\end{array}$ & This study \\
\hline \multicolumn{3}{|c|}{ Staphylococcal plasmids } \\
\hline pE194 & $\begin{array}{l}3.728 \mathrm{~kb} \text { S. aureus plasmid, inducible MLS } \\
\text { resistance (erm) }\end{array}$ & Horinouchi and Weisblum 1982 \\
\hline pLUG274 & pE194::EcoRV site in MCS & Benito et al. 2000 \\
\hline pLUG298 & pLUG274::P3 operon (nt 1819-751) & Huntzinger et al. 2005 \\
\hline pLUG300 & $\begin{array}{l}\text { pE194:: P3 promoter link to } 3^{\prime} \text {-end RNAIII (nucleotides } \\
\text { 391-514) }\end{array}$ & Benito et al. 2000 \\
\hline pLUG304 & pLUG274::rnaIII $\Delta$ nucleotides $408-451$ (RNAIII- $\Delta 13$ ) & Huntzinger et al. 2005 \\
\hline
\end{tabular}


Table 1. (continued)

\begin{tabular}{|c|c|c|}
\hline E. coli strains & Relevant characteristics & Reference/source \\
\hline pLUG324 & $\begin{array}{l}\text { pLUG274::P3 promoter (nucleotides } 1819-1569):: 3^{\prime} \text { end rnaIII } \\
\text { region (nucleotides } 394-514 \text { of RNAIII) }\end{array}$ & Huntzinger et al. 2005 \\
\hline pLUG345 & $\begin{array}{l}\text { pLUG274::agr-sa nucleotides } 1819-1475 \text { (P3 promoter to start } \\
\text { codon)::StuI :: BamHI cloning site:: linked to nucleotides } \\
\text { 1095-751 of rnaIII (transcriptional terminator) }\end{array}$ & This study \\
\hline pLUG389 & pLUG274::P3 promoter-TT (nucleotides $484-514$ ) & This study \\
\hline pLUG543 & $\begin{array}{l}\text { pLUG220::P-rpoB (nucleotides }-480 \text { to } \\
\quad+1):: \text { SA } 1000 \text { (nucleotides }+1 \text { [transcriptional start] to }+90 \text { ) }\end{array}$ & This study \\
\hline pLUG550 & pLUG345::SA1000 & This study \\
\hline pLUG653 & $\begin{array}{l}\text { pLUG220 : P-rpo } B \text { (nucleotides }-480 \text { to }+1 \text { ) }:: \operatorname{rot} \text { (nucleotides }+1 \\
\quad \text { [transcriptional start] to }+290 \text { ) }\end{array}$ & This study \\
\hline pLUG661 & $\begin{array}{l}\text { pLUG274::P3 promoter (nucleotides } 1819-1569):: \text { modified } \\
\text { 3'-end rnaIII: nucleotides } 494-502 \text { replaced by } \\
\text { GAGA (RNAIII- } \Delta 4 \text { ) }\end{array}$ & This study \\
\hline pLUG667 & $\begin{array}{l}\text { pLUG274::P3 promoter (nucleotides 1819-1569):: modified } \\
\text { 3'-end rnaIII: (RNAIII- } \Delta 1)+(\text { RNAIII- } \Delta 4)=(\text { RNAIII- } \Delta 5)\end{array}$ & This study \\
\hline
\end{tabular}

the $5^{\prime}$ side of the hairpin 13 of RNAIII by a linker of $8 \mathrm{nt}$. Each construct was then submitted to RNAfold for predicting the base pairing between each concatenated sequence. This approach allows the estimation of the hybridization of two RNA sequences and calculates the minimum free energy of hybridization. The mRNARNAIII hybrids that were considered had a minimum free energy of $-19 \mathrm{kcal} / \mathrm{mol}$ or less (Fig. 1B; Supplementary Fig. S1). Among the best candidates, we found several mRNAs that encode virulence factors (SA1000, a fibrinogen-binding protein; the staphylocoagulase precursor, protein A; and SA2353 and SA2093, two proteins homologous to the secretory antigen precursor SsaA), and the peptidoglycane hydrolase (Fig. 1B; Supplementary Fig. S1). We show here that the best target SA1000 mRNA produces a virulence factor conserved in all $S$. aureus strains, which is anchored to the cell surface and adheres to fibrinogen and fibronectin (Supplementary Fig. S2). This fibrinogen-binding protein was recently shown to contribute to bacterial adhesion and invasion of epithelial cells (Liang et al. 2006). Noticeably, we also found rot mRNA, which encodes Rot protein, a transcriptional regulator of the sar family that affects virulence gene expression (Novick 2003). In an independent search, we looked for base pairing between RNAIII and the $5^{\prime}$ leader regions of the sar family mRNAs. In addition to rot mRNA, sarT mRNA may form a duplex with RNAIII, albeit characterized by a higher minimum free energy (Supplementary Fig. S1). Note that the expression of Rot and SarT was shown to be repressed by the $a g r$ system (Schmidt et al. 2003; Geisinger et al. 2006). Other mRNA candidates encoding surface transporter proteins, and unknown proteins were also predicted (Supplementary Fig. S1). Thus, this analysis suggested that RNAIII regulates multiple targets directly and indirectly via the repression of transcriptional regulators. We analyzed the regulatory mechanisms for several potential target mRNAs that encode for virulence factors (SA1000, SA2353) and for the transcriptional regulator Rot.

\section{RNAIII rapidly forms a duplex with SA1000 mRNA covering the RBS}

The in silico data shows that SA1000 mRNA is the best candidate to form a long duplex with RNAIII. Before analyzing the formation of the RNAIII-mRNA duplex in vitro, we mapped the transcriptional start site of SA1000 mRNA by primer extension in WA400 strain ( $\Delta$ rnaIII). A major start site was detected $22 \mathrm{nt}$ upstream of the SD sequence of SA1000 mRNA (Supplementary Fig. S3). Band shift experiments were performed with a 200-nt mRNA fragment encompassing the whole $5^{\prime}$ untranslated region and the RBS. We showed that the $3^{\prime}$-end domain and RNAIII bound equally well to the 5 '-endlabeled SA1000 mRNA ( $\left.\mathrm{K}_{\mathrm{d}} 20 \mathrm{nM}\right)$, whereas the deletion of hairpin 13 in RNAIII (RNAIII- $\Delta 13$ ) failed to bind the mRNA (Supplementary Fig. S3). A time-course analysis estimates the initial rate of RNAIII binding to SA1000 mRNA to be $1( \pm 0.3) \times 10^{5} \mathrm{M}^{-1} \mathrm{sec}^{-1}$, a value close to that obtained for several efficient natural antisense RNAs (Wagner et al. 2002).

The conformation of SA1000 mRNA was probed using $\mathrm{Pb}(\mathrm{II})$-induced cleavages, RNase T1 (specific for unpaired guanines), RNase T2 (specific for unpaired nucleotides), and RNase V1 (specific for helical regions). For SA1000 mRNA, the data support the existence of the two long hairpin structures I and II (Fig. 2A). Binding of RNAIII induced structural changes in a restricted region (from A10 to A60) covering the RBS of the mRNA. Strong protections were mainly observed in hairpin I, accompanied by new RNase V1 cleavages at positions 17 and 50-53, and a new $\mathrm{Pb}(\mathrm{II})$-induced cut at position 23 (Fig. 2A). Binding of SA1000 mRNA to the $3^{\prime}$ domain or to RNAIII induced similar changes in hairpin 13. Strong protections against $\mathrm{RNase} \mathrm{T} 2$ and $\mathrm{Pb}(\mathrm{II})$ were located in region 420-439 (Fig. 2B). Concomitantly, increased cleavages were induced by RNase $\mathrm{T} 2$ and $\mathrm{Pb}(\mathrm{II})$ at positions 440 452 and by RNase V1 at positions 429, 433-434, and 438. These data are consistent with the rapid formation of the 
Boisset et al.

RNAIII-mRNA duplex of nearly 40 base pairs (bp) that overlaps the RBS of SA1000 mRNA (Fig. 2C).

The 3' domain represses the synthesis of the fibrinogen-binding protein SA1000 at the post-transcriptional level

We investigated whether the repression of SA1000 synthesis occurs through specific binding of RNAIII to SA1000 mRNA in vivo. The entire regulatory region of SA1000 mRNA was fused in frame with lacZ under the control of an $a g r$-independent promoter $(\operatorname{PrpoB})$ (Table 1). The $\beta$-galactosidase activity was determined in the $S$. aureus strains RN6390 (rnaIII $\left.{ }^{+}, a g r^{+}\right)$, which express RNAIII, and in WA400 (DrnaIII), which carries a deletion of rnaIII gene (Table 1). Complementation assays were also done in WA400 transformed with plasmids expressing either RNAIII, RNAIII- $\Delta 13$ (deletion of hairpin 13 ), or the 3 '-end domain (Fig. 3A). The $\beta$-galactosidase activity was reduced by half in RN6390 as compared with WA400 and was strongly decreased in the WA400 strains expressing either RNAIII or the 3' domain. Conversely, the expression of RNAIII- $\Delta 13$ in WA400 did not affect $\beta$-galactosidase synthesis, in agreement with the fact that RNAIII- $\Delta 13$ cannot bind to SA1000 mRNA. In the $\Delta r n c$ strain, a RN6390 derivative in which the RNase III gene $(r n c)$ has been deleted, $\beta$-galactosidase activity was enhanced as compared with RN6390 (Fig. 3A).

We also analyzed the steady-state level of SA1000 mRNA in different $S$. aureus strains in late-exponential phase (Fig. 3B). The mRNA was not detected in RN6390 $\left(\right.$ rnaIII $\left.^{+}\right)$, and conversely, its level was high in WA400

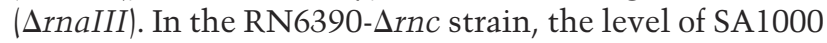
mRNA was reproducibly found to be slightly higher than in the parental RN6390 strain (Fig. 3B). This result suggests that the RNase III-dependent degradation of the mRNA contributes in part to the disappearance of the mRNA pool. Complementation assays were also done with WA400 (DrnaIII) transformed with plasmids expressing RNAIII or several variants. The expression of RNAIII, the 3' domain, or the 3' domain carrying mutations in the hairpin loop $14(\Delta \mathrm{L} 14)$ strongly reduced the level of SA1000. Conversely, significant levels of the mRNA were still detected in WA400 expressing RNAIII$\Delta 13$ or H14 (Fig. 3B, cf. lanes 7 and 9), and they were almost identical to those found in WA400 transformed with the empty plasmid. Taken together, these data show that hairpin 13 is the main regulatory element of RNAIII required for SA1000 repression, and that RNase III contributes to the efficiency of repression.

\section{$H f q$ protein is not required for the regulation of SA1000 expression}

The bacterial Sm-like Hfq protein is a key player in translational control mediated by sRNAs (Valentin-Hansen et al. 2004). Therefore, we analyzed the role of $S$. aureus Hfq in RNAIII-dependent regulations. Allelic replacement of the entire coding sequence of $h f q$ gene by the cat (chloramphenicol resistance) gene was done in RN6390 (LUG911) (Table 1). The mutant $\Delta h f q$ strain formed normal and hemolytic colonies on blood-agar

Figure 3. RNAIII and its $3^{\prime}$ domain regulate the expression of SA1000 mRNA at the post-transcriptional level. (A) $\beta$-Galactosidase activity measured from $\operatorname{PrpoB}$ $(+1 /+200):: 1 a c Z$ fusions in $S$. aureus RN6390 (rnaIII $\left.{ }^{+}, a g r^{+}\right)$, RN6390- $\Delta r n c$ (deletion of $r n c$ gene encoding RNase III), WA400 (DrnaIII), WA400 + RNAIII, WA400 + 3' domain, WA400 + RNAIII$\Delta 13$ (RNAIII deleted of hairpin 13), and WA400 + H14 (expression of the hairpin 14 of RNAIII). The $\beta$-galactosidase activity was normalized for total cell density and is represented as a percentage of the uninhibited control (WA400). The results represented a mean of three independent experiments. (B) Northern blot analysis of SA1000 mRNA levels in different strains. RNAs from post-exponential phase cultures were hybridized with probes corresponding to RNAIII, the 3' domain,
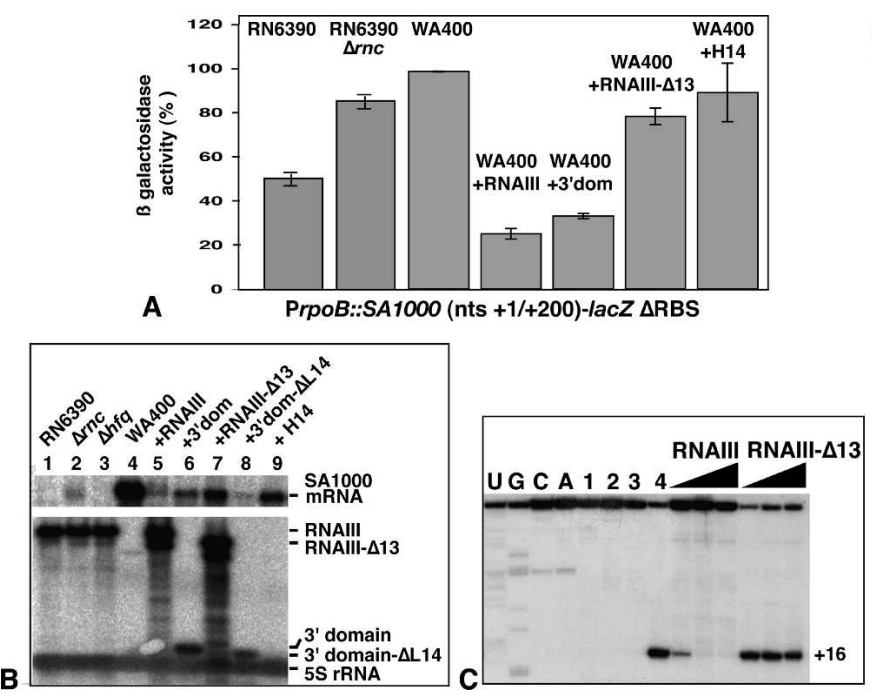
SA1000 mRNA, and 5S rRNA as internal control: RN6390 (lane 1), RN6390- $\Delta r n c$ (lane 2), RN6390- $\Delta h f q$ (deletion of the $h f q$ gene) (lane 3), WA400 (lane 4), WA400 + RNAIII (lane 5), WA400 + 3' domain (lane 6), WA400 + RNAIII- $\Delta 13$ (lane 7), WA400 + 3' dom- $\Delta$ L14 (AACCCUCCC was changed by GAGA in the hairpin loop 14) (lane 8), and WA400 + H14 (lane 9). (C) Formation of the complex between SA $1000 \mathrm{mRNA}(15 \mathrm{nM})$, S. aureus $30 \mathrm{~S}$ ribosomal subunits $(100 \mathrm{nM})$, and initiator tRNA $(1 \mu \mathrm{M})$ monitored in the absence (lane 4) or presence of increasing concentrations of RNAIII or RNAIII- $\Delta 13(15,75$, and $150 \mathrm{nM})$. The toeprint is indicated. Incubation controls of SA1000 mRNA alone (lane 1) and with RNAIII (lane 2) or RNAIII- $\Delta 13$ (lane 3). (Lanes $U, G, C, A$ ) Dideoxy-sequencing reactions. (D) RNase III hydrolysis of 5'-end-labeled SA1000 mRNA, free (-) or with RNAIII (+). (Lane T) RNase T1. (Lane $L$ ) Alkaline ladders. Arrows indicate the RNase III cleavages. 
medium plates, and cell growth was not affected in rich medium. The stability of RNAIII was not altered in the $\Delta h f q$ strain (Supplementary Fig. S3). Furthermore, Hfq protein did not alter the formation of SA1000 mRNARNAIII complex in vitro (data not shown), and in vivo SA1000 mRNA was not detectable at the late exponential phase in $\Delta h f q$ strain as well as in RN6390 (Fig. 3A, lane 3). These data strongly suggest that $S$. aureus Hfq is not a key player in the regulation of SA1000 expression.

The RNAIII-SA1000 mRNA duplex prevents

the binding of the ribosome and promotes

RNase III cleavages

RNAIII covers the RBS of SA1000 mRNA; therefore, we tested whether the duplex was able to prevent ribosome binding using toeprinting assays. The ternary initiation complex constituted by S. aureus $30 \mathrm{~S}$ subunits, the initiator tRNA ${ }^{\text {Met }}$, and SA1000 mRNA blocked the elongation of a cDNA primer by reverse transcriptase (RT), and produced a toeprint $16 \mathrm{nt}$ downstream from the initiation codon (Fig. 3C). Binding of RNAIII significantly decreased the yield of the toeprint since $80 \%$ of inhibition was observed at equimolar concentrations of RNAIII and SA1000 mRNA (Fig. 3C). Since the ternary complex forms irreversibly, inhibition was only observed when initiator tRNA was added after RNAIII. The addition of RNAIII- $\Delta 13$, which does not form a complex with SA1000 mRNA, did not alter ribosome binding; $<20 \%$ of the inhibition was observed at a 20 -fold molar excess of RNAIII- $\Delta 13$ (Fig. 3C). Thus, inhibition of ribosome binding to SA1000 mRNA resulted primarily from a direct interaction of the hairpin 13 of RNAIII to the mRNA.

As RNase III is required for efficient repression in vivo, we analyzed whether this enzyme can cleave the duplex in vitro. A His-tagged RNase III from S. aureus was purified, and the RNase III-dependent cleavages were analyzed on the free RNAs as well as on the native RNAIIISA1000 mRNA complex (Fig. 3D). In SA1000 mRNA, $S$. aureus RNase III cleaved the long hairpin structure II at positions A91, A100, A141, and A149. When end-labeled SA1000 mRNA was incubated with RNAIII, two new strong cleavages occurred at positions U37 and A42 in the mRNA (Fig. 3D). Similarly, new cleavages dependent on mRNA binding were detected at A416 and A418 of labeled RNAIII (data not shown). Thus, SA1000 mRNA and the resulting duplex were both cleaved by the enzyme.

The 3' domain represses the synthesis of another virulence factor, a secretary antigen precursor using a shared mechanism

Among the predicted mRNA targets, SA2353 mRNA, which encodes a secretory antigen precursor, can potentially form a hybrid with RNAIII characterized by a free energy close to that of the spa mRNA-RNAIII hybrid (Fig. 1B). The steady-state level of SA2353 mRNA was analyzed in different $S$. aureus strains in early and late exponential phase cultures (Fig. 4A). In RN6390 (rnaIII ${ }^{+}$, the expression of the mRNA is dependent on the growth

phase since the level of the mRNA is strongly decreased at the stationary phase as soon as the RNAIII is produced. The same data were obtained with the strain deleted of the $h f q$ gene, while a significant level of SA2353 mRNA was still observed at the late-exponential phase in RN6390- $\Delta r n c$. The mRNA was also detected in the WA400 (DrnaIII) strain carrying the empty plasmid or expressing hairpin 14 of RNAIII. Conversely, SA2353 mRNA was barely detectable in WA400 transformed with a plasmid expressing RNAIII, its 3' domain, or the 3' domain- $\Delta$ L14 (Fig. 4A). These experiments argue for an RNAIII-dependent repression of SA2353 mRNA at the late-exponential phase of growth. Furthermore, as for SA1000, depletion of the repressed mRNA requires the RNase III (Fig. 4A).

For further in vitro studies, we determined the transcriptional start of SA2353 mRNA in WA400 using 5'RACE (rapid amplification of cDNA ends) analysis. This start occurred $126 \mathrm{nt}$ upstream of the AUG codon of the mRNA. Thus, the whole leader region of the mRNA encompassing the RBS and part of the coding sequence (243 nt) was produced in vitro. Preliminary experiments indicate that RNAIII and its 3' domain rapidly form a stable complex with SA2353 mRNA in vitro (data not shown). Next, we tested the effect of RNAIII on the formation of the ternary ribosomal complex SA2353 mRNA-30S-tRNA ${ }_{f}^{\text {Met }}$ in vitro (Fig. 4B). The addition of increasing concentrations of RNAIII or the $3^{\prime}$ domain

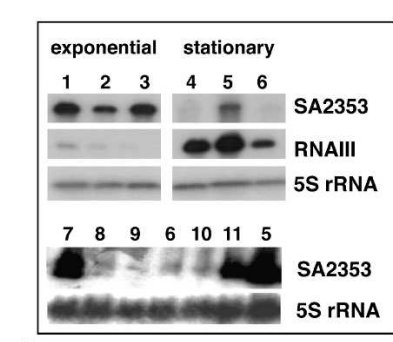

A

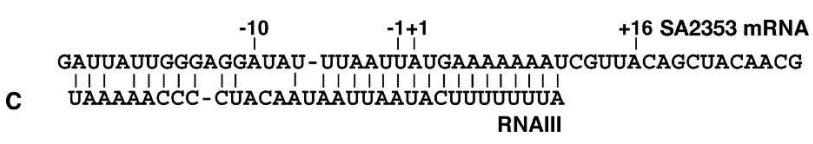

Figure 4. RNAIII-dependant regulation of SA2353 mRNA. (A) Northern blot analysis of SA2353 mRNA levels in different strains. RNAs were prepared from early exponential phase (OD 0.5 at $600 \mathrm{~nm}$ ) (lanes 1-3) and from stationary phase (OD 5.0 at $600 \mathrm{~nm}$ ) (lanes 4-11) cultures hybridized with probes corresponding to SA2353 mRNA, RNAIII, and 5S rRNA: RN6390

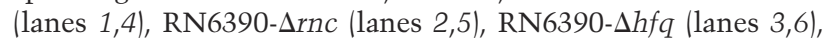
WA400 + H14 (lane 7), WA400 + RNAIII (lane 8), WA400 + 3' domain (lane 9), WA400 + 3' dom- $\Delta$ L14 (lane 10) (see Fig. 2B), and WA400 transformed with the empty plasmid pE194 (lane 11). (B) Binding of RNAIII to SA2353 mRNA prevents ribosome binding. Ternary (mRNA-tRNA ${ }_{\mathrm{f}}^{\text {Met }}$-ribosome) complex incubated in the absence (lane 3) or presence of increasing concentrations of RNAIII (100 nM, lane 4; $500 \mathrm{nM}$, lane 5), the 3' domain (100 nM, lane 6; $400 \mathrm{nM}$, lane 7), or RNAIII- $\Delta 13$ (100 $\mathrm{nM}$, lane 8; $600 \mathrm{nM}$, lane 9). (Lanes $U, G)$ Dideoxy-sequencing reactions. (C) Potential interactions between SA2353 mRNA and the hairpin 13 of RNAIII. 
Boisset et al.

significantly reduced the yield of the toeprint at position +16 , and concomitantly, an RT pause appeared at position $\mathrm{G}+3$. Conversely, RNAIII- $\Delta 13$ failed to compete with the 30S subunit binding, but the RT pause at position +3 disappeared, revealing the signature of the duplex formed between hairpin 13 and the RBS of SA2353 mRNA (Fig. 4C). Thus the 3' domain of RNAIII forms a stable complex with SA2353 mRNA that is sufficient to prevent ribosome binding in vitro and to induce efficient repression of SA2353 mRNA in vivo. RNase III also appears to be involved in rapid depletion of the repressed mRNA pool.

RNAIII interacts with rot $m R N A$, encoding a transcriptional regulator, via several loop-loop interactions

It was recently shown that RNAIII represses the synthesis of Rot, a repressor of exoproteins, at the translational level (Geisinger et al. 2006). This inhibition would be dependent on an interaction between distant regions of RNAIII and the 5' leader region of rot mRNA. Indeed, three hairpin motifs of RNAIII $(\mathrm{H} 7, \mathrm{H} 13$, and H14) carry similar sequences that could potentially base-pair with three complementary UUGGGA sequences, including the SD sequence (GGGAG) of rot mRNA (Fig. 1). While the previous genetic analysis was focused on two of these domains, H7 and H14 (Geisinger et al. 2006), noticeable base complementarities were also observed with the hairpin 13 of RNAIII (Fig. 1B). Using gel retardation assays, we show that the $3^{\prime}$ domain and RNAIII bind equally well to rot mRNA ( $\left.\mathrm{K}_{\mathrm{d}} 10 \mathrm{nM}\right)$ (Supplementary Fig. S3). Next, we probed the structure of rot mRNA, either free or bound to RNAIII, using several RNases (Fig. 5A; Supplementary Fig. S4). Different variants of RNAIII were used to monitor the reactivity changes in rot mRNA upon binding. These RNAs include RNAIII$\Delta 14$; RNAIII- $\Delta 13$; RNAIII- $\Delta 7-9$; the 3 '-end domain, which carries two out of the three redundant hairpin motifs; and the isolated hairpins 7, 13, and 14 (Fig. 1).

\section{A}

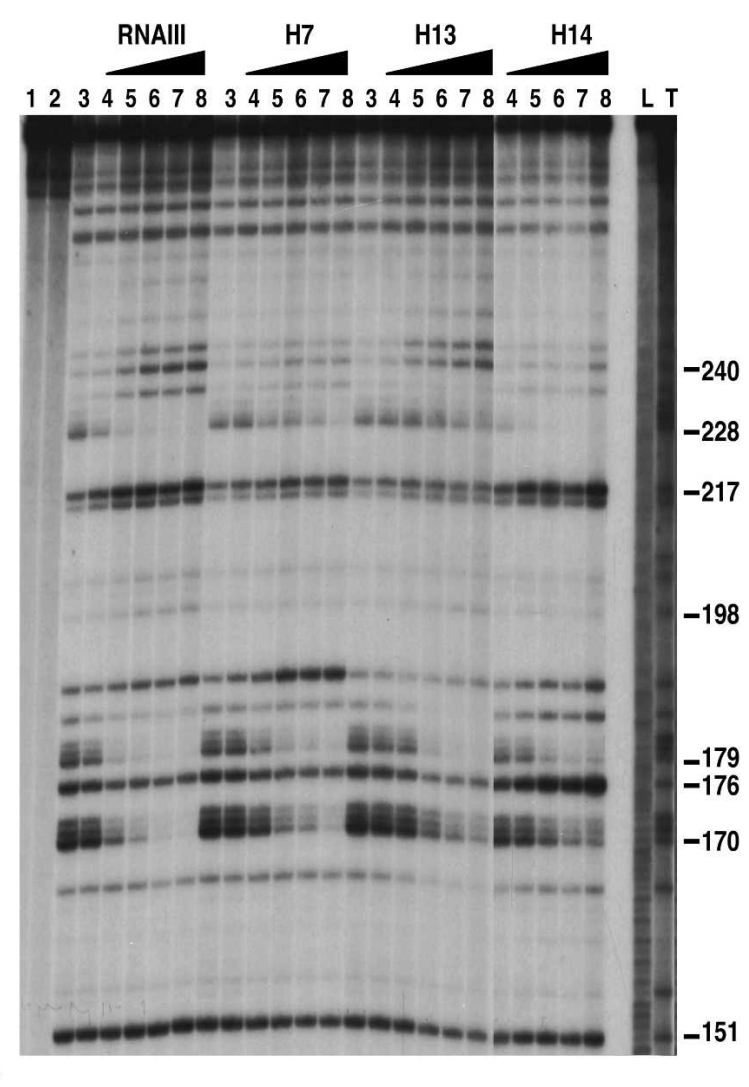

C

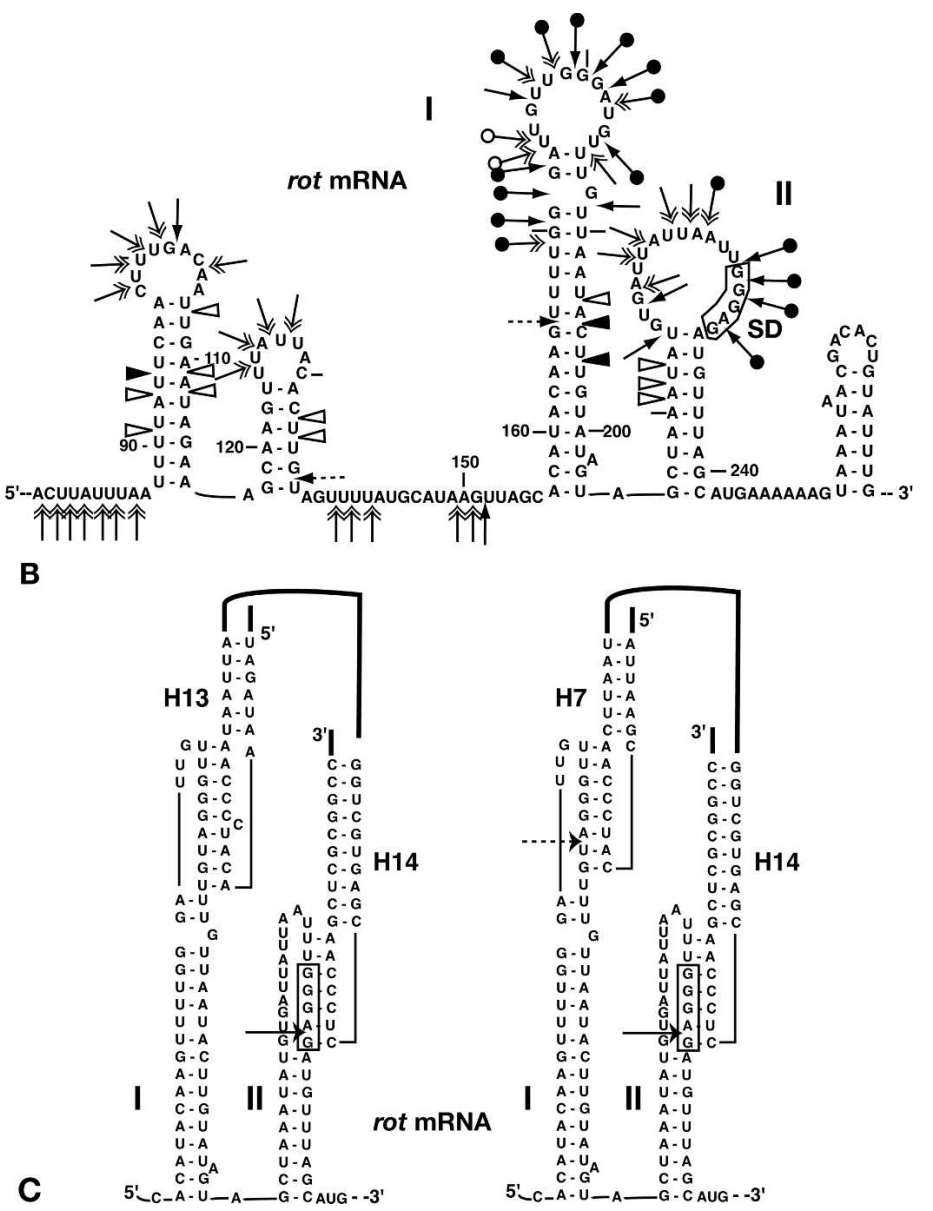

Figure 5. RNAIII binds to rot mRNA. (A) RNase T1 hydrolysis of 5 '-end-labeled rot mRNA either free (lane 3 ) or in the presence of increasing concentrations of RNAIII and of the isolated hairpins H7, H13, or H14. (Lanes 4-8) Shown are 1, 10, 50, 100, and 250 nM, respectively. (Lanes 1,2) Incubation controls in the absence (lane 1) or presence (lane 2) of RNAIII. (Lane T) RNase T1. (Lane $L$ ) Alkaline ladders. (B) Probing data shown on the secondary structure of rot mRNA. Enzymatic cleavages are given as follows: RNase T1 $(\rightarrow)$, RNase T2 $(\rightarrow)$, and RNase V1 moderate $(\triangle)$ and strong $(-$ ) cleavage. Reactivity changes induced by complex formation are indicated as follows: Black or empty circles denote strong and moderate protection, respectively. $(C)$ Models of the RNAIII-rot mRNA complex with the RNase III cleavages denoted by arrows. 
Binding of RNAIII induced protection in rot mRNA, mainly at the purine-rich GGGA sequences located in two apical loops (nucleotides G170-G184, and G227G232) (Fig. 5B). Strikingly, binding of RNAIII- $\Delta 7-9$, RNAIII- $\Delta 13$, RNAIII- $\Delta 14$, or the 3 ' domain induced similar effects on rot mRNA structure (Supplementary Fig. S4). Therefore, two out of the three hairpin domains of RNAIII were sufficient to promote identical footprints as did RNAIII in rot mRNA. We also tested whether the isolated hairpin $(\mathrm{H} 7, \mathrm{H} 13$, or $\mathrm{H} 14)$ bind rot mRNA in a similar way, using RNase T1 hydrolysis. The results show that the hairpins bind with a lower binding affinity to rot mRNA than RNAIII or the 3' domain. Hairpin 14 protects loop II of rot mRNA at a lower concentration than loop I, whereas hairpins 13 or 7 interact first with loop I and at higher concentrations with loop II (Fig. 5A). Binding of rot mRNA to end-labeled RNAIII or the $3^{\prime}$ domain induced correlated protections restricted to the complementary loop sequences of hairpins 7, 13, and 14 (data not shown).

Taken together, these data indicate that the three hairpins 7,13 , and 14 are all capable of binding to the three UUGGGA motifs, albeit with a significant preference of hairpin 14 for the SD sequence of rot mRNA. The fact that changes are only restricted to the redundant and complementary sequences favors the existence of several loop-loop interactions rather than the formation of an extended duplex as predicted by the in silico approach (Figs. 1B, 5C). The propagation of the initial intermolecular helix is probably stopped due to the topological stress.

Two loop-loop interactions are required for efficient repression of rot $m R N A$ translation

In order to test the consequence of the $3^{\prime}$ domain of RNAIII on regulation in vivo, we fused the regulatory region of rot with lacZ downstream from an agr-independent promoter (PrpoB) (Huntzinger et al. 2005). Determination of the transcriptional start of rot mRNA in RN6390 using primer extension and 5'RACE experiments revealed one major start site at $245 \mathrm{nt}$ upstream of the AUG codon and several shorter RNA transcripts, probably originating from internal cleavage events. The 5' leader sequence of the primary rot mRNA transcript, containing the region that binds RNAIII in vitro, was fused with lacZ. The $\beta$-galactosidase activity was assayed in the $S$. aureus strains RN6390 (rnaIII $\left.{ }^{+}\right)$ and WA400 (DrnaIII). The expression of the $3^{\prime}$ domain in WA400 strongly repressed $\beta$-galactosidase activity, as did RNAIII; i.e., 70\%-80\% inhibition was observed as compared with WA400 (Fig. 6A). However, mutations in the hairpin loop 14 of the $3^{\prime}$ domain $(\Delta \mathrm{L} 14)$ decrease the RNAIII-dependent $\beta$-galactosidase synthesis inhibition to only $20 \%$, suggesting that the hairpin 13 by itself is not sufficient to cause efficient repression (Fig. 6A).

We further tested whether RNAIII and its derivatives were able to prevent ribosome binding at rot mRNA using toeprinting (Fig. 6C). While rot mRNA carries two potential RBSs, the experiments revealed one single stop at A258. Thus, the RBS contains the SD sequence GGGAG232. Interestingly, the RNAIII mutants carrying only two redundant hairpin motifs (H7-H14 [RNAIII$\Delta 13$ ], H7-H13 [RNAIII- $\Delta 14$ ], or H13-H14 [RNAIII$\Delta 7-9,3^{\prime}$ domain]) competed with the 30 S subunit as efficiently as RNAIII (data not shown). However, even high concentrations of the isolated hairpin $(\mathrm{H} 7, \mathrm{H} 13$, or H14) had no similar effect on ribosome binding (Fig. 6C). These experiments indicate that the $3^{\prime}$ domain is sufficient to repress rot mRNA translation initiation, and that two loop-loop interactions are required for full repression.

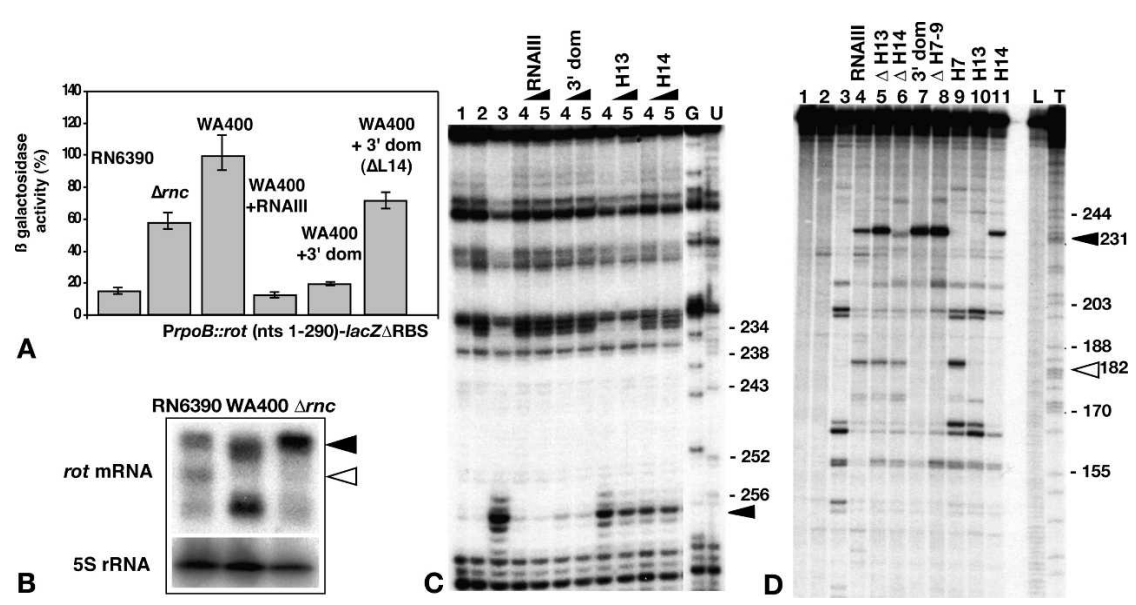

Figure 6. RNAIII regulates the expression of rot mRNA at the post-transcriptional level. (A) $\beta$-Galactosidase activity measured from $\operatorname{PrpoB}(+1 /+290)::$ rot fusions in $S$. aureus RN6390 (rnaIII ${ }^{+}$, agr $\left.^{+}\right), \mathrm{RN} 6390-\Delta r n c$, WA400 (srnaIII), WA400 + RNAIII, and WA400 + 3' domain, and WA400 $+3^{\prime}$ domain mutated in loop $14(\Delta \mathrm{L} 14)$. The legend is identical to Figure 3A. (B) Northern blot analysis of rot mRNA levels in different strains. RNAs from late-exponential phase cultures were hybridized with probes corresponding to rot mRNA and 5S rRNA: RN6390, WA400, and RN6390-srnc. Full and empty arrows denote full-length mRNA and a fragment, respectively. $(C)$ Formation of the complex between rot mRNA, S. aureus $30 \mathrm{~S}$ ribosomal subunits, and $\mathrm{tRNA}_{\mathrm{f}}{ }^{\mathrm{Met}}$ monitored in the absence (lane 3 ) or presence of increasing concentrations of RNAIII, the 3' domain $(0.1 \mu \mathrm{M}$, lane 4; $0.25 \mu \mathrm{M}$, lane 5), and the hairpin 13 or $14(0.5 \mu \mathrm{M}$, lane 4; $1 \mu \mathrm{M}$, lane 5). (Lanes $U, G)$ Dideoxy-sequencing reactions. An arrow denotes the toeprint. (D) RNase III hydrolysis of 5'-end-labeled rot mRNA in the absence (lane 3) or presence of an excess of RNAIII variants. (Lanes 4-8) RNAIII, RNAIII- $\Delta 13(\Delta \mathrm{H} 13)$, RNAIII- $\Delta 14(\Delta \mathrm{H} 14), 3^{\prime}$ domain (3' dom), and RNAIII- $\Delta 7-9$ $(\Delta \mathrm{H} 7-9)$ at $100 \mathrm{nM}$, respectively. (Lanes 9-11) Isolated hairpins 7 (H7), 13 (H13), and 14 (H14) at $200 \mathrm{nM}$, respectively. (Lanes 1,2) Incubation controls in the absence (lane 1) or presence (lane 2) of RNAIII. (Lane T) RNase T1. (Lane L) Alkaline ladders. Arrows show cleavages, which occur in rot-RNAIII complex. 
A specific signature of RNase III cleavage in rot mRNA when bound to RNAIII

We previously showed that RNase III is associated with the regulatory function of RNAIII (Huntzinger et al. 2005). Here we tested the expression of the rot-lac $Z$ reporter construct in the $\Delta r n c$ strain. The results showed that the $\beta$-galactosidase activity was increased in the $\Delta r n c$ strain as compared with RN6390 (rnaIII), suggesting that RNase III contributed to repression efficiency (Fig. 6A). Previous Northern blot experiments have shown that the half-life of rot mRNA does not significantly vary in RN6390 and $\Delta a g r$ strains (Geisinger et al. 2006). However, Northern blot experiments performed on total RNAs extracted in the late exponential phase revealed a shorter fragment of rot mRNA that was absent in WA400 (srnaIII) (Fig. 6B). Interestingly, this fragment was also absent in the RN6390- $\Delta r n c$ strain while the amount of full-length mRNA was significantly increased. These data indicate that a cleavage site in rot mRNA is dependent on both RNAIII binding and RNase III activity.

RNase III cleavage assays were further analyzed on the free RNAs and on native RNAIII-rot mRNA complexes (Fig. 6D). No specific RNase III cleavages were observed in the 5 '-end-labeled RNAIII when bound to rot mRNA (data not shown). When labeled rot mRNA was incubated with RNAIII, one strong RNase III-dependent cleavage appeared at A231 and a weaker one at A182 (Fig. 6D) in the two GGGA sequences that base pair with RNAIII. The strong cut, located in the SD of rot mRNA, resulted from binding of hairpin 14. Indeed, this cleavage was absent in complexes formed between rot mRNA and hairpin 13 , or RNAIII- $\Delta 14$. Furthermore, binding of hairpin 7 to rot mRNA induced a cleavage at A182, which did not occur in rot mRNA bound to the $3^{\prime}$ domain or to RNAIII- $\Delta 7-9$. These two specific RNase III cleavages might result from coaxial stacking of several helices forming a long helical structure recognized by the RNase (Fig. 5C). In agreement with the footprinting experiments, these data indicate that hairpin 14 binds preferentially to the SD sequence, and that RNase III cleavage may help to inactivate rot mRNA translation.

The 3' domain of RNAIII indirectly activates the expression of several exoproteins

Given that the $3^{\prime}$ domain of RNAIII might regulate numerous genes, we analyzed the changes induced by the $3^{\prime}$ domain on the extracellular proteome, which includes several known virulence factors (Sibbald et al. 2006). This was done by two-dimensional gel electrophoresis/ mass spectroscopy (MS) on extracts prepared from different strains: RN6390 (rnaIII ${ }^{+}$), WA400 (srnaIII), and WA400 transformed either by an empty plasmid or by the plasmid expressing the $3^{\prime}$ domain. Proteins isolated from exponential phase cultures of the different strains were solubilized for 2-DGE and arrayed using $\mathrm{pH}$ 3-10 IPG two-dimensional gels (Supplementary Fig. S5). Previous work has shown that the synthesis of many of the exoproteins was drastically altered in the $\Delta a g r$ strain (Cordwell et al. 2002). We show here that the expression of the $3^{\prime}$ domain significantly restored the synthesis of several exoproteins, including hemolysins $(\alpha-$ and $\beta$ hemolysins) and triacylglycerol lipase, and of several exoproteases (cysteine protease SspB, serine proteases SplA-F).

\section{Discussion}

S. aureus is a Gram-positive pathogen responsible for a wide variety of human diseases, and is one of the leading causes of hospital and community-acquired infections. The high diversity of clinical infections caused by $S$. aureus depends on the expression of numerous virulence factors and stress response pathways, which require the coordinated action of several regulators. Among these intracellular regulators, RNAIII plays a key role in the quorum sensing-dependent central regulatory circuit and coordinately regulates numerous virulence-associated genes (Novick 2003). However, the mechanistic aspects of these regulations have been elucidated only for a few cases (Morfeldt et al. 1995; Huntzinger et al. 2005; Geisinger et al. 2006). The present study not only extends the number of target genes for which a mechanistic model of regulation can be proposed, but also reveals that a specific domain of RNAIII, the 3' domain, acts primarily as an antisense RNA by targeting a class of mRNAs encoding virulence factors and the transcriptional regulator Rot.

The 3' domain of RNAIII causes direct repression of SA1000 mRNA (coding for a newly adhesin) translation and induces its rapid degradation in a process that is dependent on the double-strand-specific RNase III (Fig. 7A). Similar results were obtained for SA2353 mRNA (encoding a secretory antigen precursor): In vivo, the depletion of the mRNA pool requires RNAIII or its $3^{\prime}$ domain along with RNase III, and in vitro, the formation of the SA2353 mRNA-RNAIII duplex prevents the binding of the ribosome. The in silico approach predicted several other target mRNAs such as coa (coagulase), lytM (petidoglycane hydrolase), SA2093 (homologous to SsaA), and SA1183 (a choline-glycine transporter), whose expression was shown to be repressed by the agr system, and most likely by RNAIII (Benito et al. 1998; Ramadurai et al. 1999; Dunman et al. 2001). Hence, the mechanism proposed for spa, SA1000, and SA2353 repression may be generalized to many other mRNAs (Fig. 1B; Supplementary Fig. S1). Note that the SA1000 and spa mRNAs have similar structural features; they both carry a 5' hairpin structure with the SD sequence in the apical loop and a long hairpin structure located downstream from the complementary nucleotides (Fig. 7A). Structure prediction and probing experiments also suggested that coa mRNA has a very similar structural organization (C. Chevalier and P. Romby, unpubl.). We propose that the $5^{\prime}$ hairpin motif facilitates the initial RNAIII-mRNA contacts. Indeed, fast pairings are usually a consequence of a limited number of initial interactions involving either loop-loop or unpaired regionloop interactions (Wagner et al. 2002). Thus the nucleation step probably involves base pairings between loop 13 of RNAIII and the SD sequence located in the first apical loop of SA1000 and spa mRNAs. These interac- 


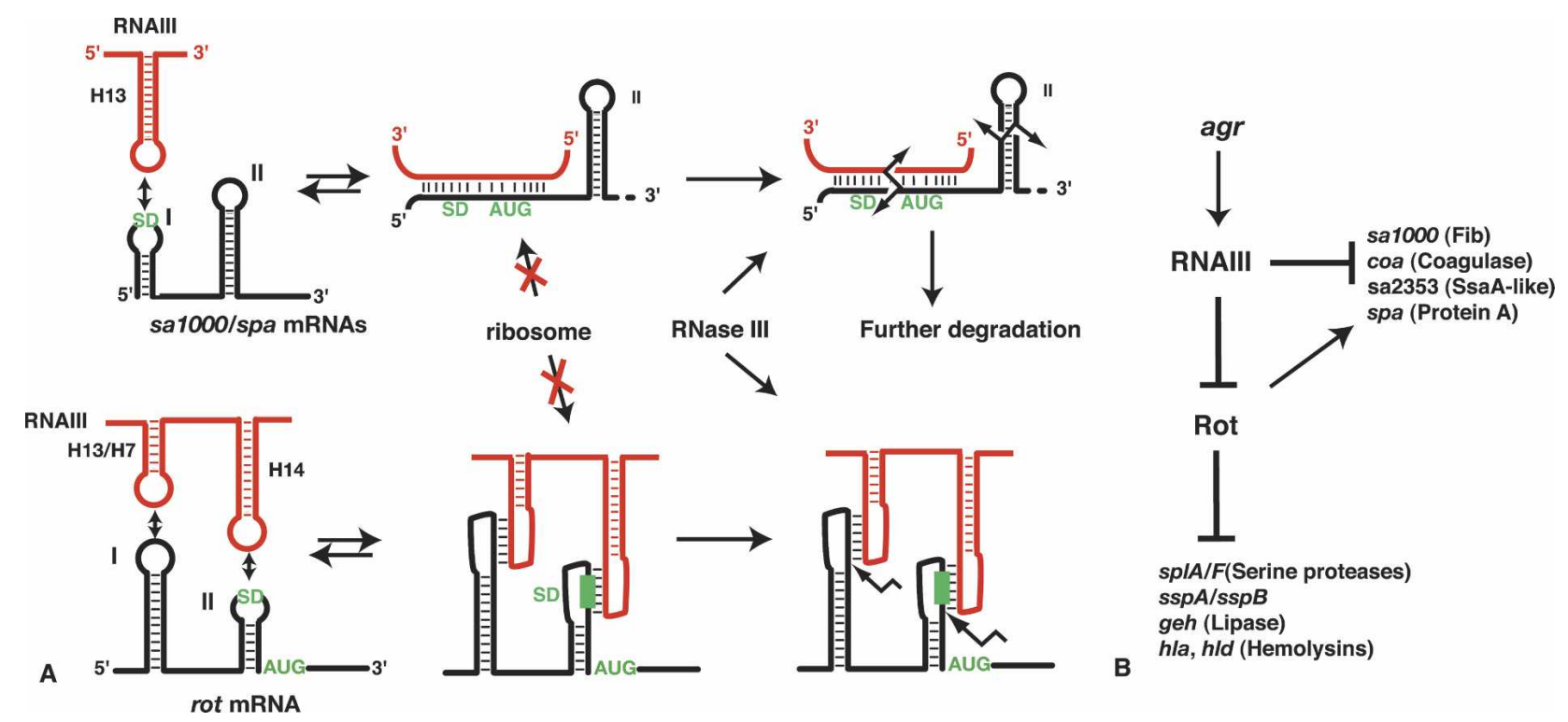

Figure 7. Schematic view of the antisense regulatory mechanisms. (A) RNAIII binds to its target mRNAs via one (top panel) or two (bottom panel) loop-loop interactions. In the first case, the initial base pairings are propagated, leading to the formation of an extended irregular duplex. In both cases, binding of RNAIII hinders ribosome binding and promotes the access to RNase III. For rot mRNA, total depletion of the mRNA pool is not observed. SD and AUG are in green. RNAIII is in red, and the mRNA target in black. (B) RNAIII represses directly the synthesis of adhesins and surface proteins and of Rot, which in turn represses the synthesis of exotoxins and activates the synthesis of adhesin proteins.

tions, rich in GC base pairs, are then subsequently propagated to form extended duplex of $>30$ bp (Fig. 1B). The formation of such long duplexes explains why RNase III initiates the rapid decay of these mRNAs. In addition, RNase III induced cleavages in these duplexes and also in the long downstream hairpin of mRNAs, which may provide access to several other endoribonucleases or exoribonucleases for further depletion of the mRNA pool (Fig. 7A). In E. coli, sRNA-dependent translational repression is also followed by rapid decay of the repressed mRNA. However, the enzyme that initiates degradation is the single-strand-specific RNase E since many duplexes involve $<20$ bp (Morita et al. 2005). In E. coli, degradation of repressed mRNAs is probably a consequence of ribosome exclusion rather than the primary event because the translational repression can occur in the absence of mRNA destabilization (Morita et al. 2006). In S. aureus, we postulate that RNAIII-dependent inhibition of the ribosome is coupled to the RNase III-dependent cleavage to render the arrest of translation irreversible. This event might be facilitated by the fact that RNAIII guides the endoribonuclease to the repressed mRNAs in vivo since the enzyme was purified through association with RNAIII coated beads (Huntzinger et al. 2005).

We also show that RNAIII or its 3' domain represses rot mRNA translation initiation through base-pairing with two short sequences, one of which overlaps with the SD sequence and the other resides further upstream within the 5' leader region (Figs. 5, 7A). Our data indicate that hairpin 14 binds preferentially to the SD sequence of rot mRNA to form a perfect match of seven contiguous base pairs. Moreover, the 3' domain and RNAIII variants, which contain only two of the hairpin loops, bind equally well to rot mRNA and compete with the ribosome as efficiently as RNAIII. Therefore, we suggest that several coexisting complexes with two loop-loop interactions occur (Fig. 5C, H7-H14 and H13-H14), reminiscent of the E. coli OxyS-fhlA mRNA system (Argaman and Altuvia 2000). Our data also stress that one looploop interaction is not sufficient to block the access of the ribosome in vitro and for efficient repression in vivo. Since a large proportion of $S$. aureus mRNAs contain a strong SD sequence (Chang et al. 2006), the three hairpin motifs $(7,13$, and 14) of RNAIII could potentially interact with the SD of many mRNAs. To prevent such global effects, which would be detrimental for the bacteria, specificity is obtained either by propagating the initial contacts into more extended duplexes, as seen in the target mRNAs encoding virulence factors (protein A, SA1000, SA2353, coagulase), or by the addition of a second loop-loop interaction, as shown for rot mRNA (Fig. 7A). It is important to note that the inhibition of rot mRNA translation is not followed by total depletion of the mRNA pool although part of rot mRNA is cleaved by RNase III (Fig. 5; Geisinger et al. 2006). Rot is a pleiotropic transcriptional regulator, and RNA regulation is likely to be more dynamic in this case in order to rapidly respond to specific cellular needs.

A main difference with sRNA-dependent regulation in $E$. coli and $S$. aureus is the functional requirement of the Sm-like protein Hfq. In E. coli, Hfq stabilizes sRNA or facilitates its interaction with the target mRNAs (Storz et al. 2005). Mutations in $h f q$ also decrease virulence in several pathogens (for review, see Vogel and Papenfort 2006). RNAIII is a potential target of $S$. aureus Hfq in vivo (Huntzinger et al. 2005). However, the protein ex- 
erts no major effect in vivo on SA1000, SA2353, rot mRNA levels, and RNAIII stability and, in vitro, on RNAIII-mRNA complex formation. Furthermore, deletion of $h f q$ had no significant effect on virulence in Caenorhabditis elegans (S. Boisset and F. Vandenesch, unpubl.). Our data are in agreement with recent works that show the deletion of Hfq had no noticeable effect on virulence gene expression and that this protein is not highly expressed in S. aureus (Geisinger et al. 2006; Bohn et al. 2007). The facts that the structures of RNAIII and its target mRNAs have evolved to promote fast pairings and the duplexes formed are substrates of RNase III may obviate the need of Hfq protein.

Several of the proteins (protein A, coagulase) regulated by RNAIII are considered major virulence factors, produced by all $S$. aureus clinical isolates. We show that SA1000 is a novel conserved fibrinogen-binding protein in agreement with recent observations that SA1000 belongs to the bacterial adhesion machinery and is required for virulence (Liang et al. 2006). Like Efb (extracellular fibrinogen-binding protein) or Eap (extracellular adhesion protein), SA1000 does not contain the C-terminal LPXTG consensus sequence that is required for the processing and anchorage of mature adhesins to the peptidoglycan, and probably interacts with negatively charged surface molecules, such as lipoteichoic acids, by noncovalent electrostatic or hydrophobic interactions (Hussain et al. 2001). The function of proteins SA2353 and SA2093 in virulence is still unknown. However, these two proteins are homologous to the staphylococcal secretory antigen SsaA (Dubrac and Msadek 2004), which is predicted to play a role in the pathogenesis of $S$. epidermidis infective endocarditis (Lang et al. 2000). Thus, RNAIII seems to directly repress the synthesis of proteins that are required for the earlier phase of the infection, as several of them favor the bacterial adherence (protein A, fibrinogen-binding protein SA1000, coagulase), protect the bacteria against the host defense (protein A, staphylococcal secretary antigens), or are part of the cell wall metabolism (peptidoglycane hydrolase). Interestingly, many of these proteins are exposed at the surface of $S$. aureus, an observation also made for several sRNAs in enterobacteria and their pathogenic relatives (for reviews, see Guillier et al. 2006; Vogel and Papenfort 2006). Modulation of membrane and surface properties in bacterial pathogens by sRNAs may contribute to virulence in different ways-by ensuring the entry of essential nutrients, by excluding toxic compounds, and by combating the host defense mechanisms.

RNAIII is expected to initiate regulatory cascades to modulate the expression of multiple downstream genes involved in or required for pathogenesis. Previous studies have shown that in vitro repression of cell wall proteins occurs as soon as RNAIII is produced in the exponential phase, whereas a delay is observed for the activation of many of the exoproteins, suggesting that RNAIII regulates an intermediary factor (Vandenesch et al. 1991; Balaban and Novick 1995). Rot protein might be this factor since it represses the transcription of several exoproteases and toxins, conferring a pattern of expres- sion opposite to that seen with RNAIII (Geisinger et al. 2006; Oscarsson et al. 2006). The 3' domain efficiently represses the expression of Rot and of several virulence factors and concomitantly activates the synthesis of many exoproteases. Since we did not observe obvious complementarities between the $3^{\prime}$ domain and these mRNAs, we suggest that the activation of the synthesis of the exoproteases by the 3 ' domain might be the consequence of its direct action on rot mRNA translation (Fig. 7B). Furthermore, Rot protein was also shown to activate the expression of cell surface proteins (Said-Salim et al. 2003; Oscarsson et al. 2006). Hence, several genes appear to be controlled at multiple levels by RNAIII (Fig. 7A). This is particularly well elucidated for spa, whose promoter activity, translation initiation, and mRNA degradation are negatively controlled by RNAIII and its 3' domain (Huntzinger et al. 2005). Rot binds to the promoter region of spa and activates transcription (Oscarsson et al. 2005). We therefore propose that the expression of spa mRNA is directly repressed by RNAIII via an antisense mechanism and indirectly through the repression of rot mRNA translation. Such a situation is probably more common than initially expected and is likely the case for coagulase, which is also repressed at multiple levels by RNAIII (Lebeau et al. 1994; Benito et al. 1998). Finally, transcriptomic analysis has revealed many overlapping effects between several two-component systems and the quorum-sensing system (Dunman et al. 2001; Dubrac and Msadek 2004; Liang et al. 2005; Luong et al. 2006; Oscarsson et al. 2006). These multiple interconnections indicate that RNAIII can target other intermediary regulatory proteins. For example, a potential base pairing is predicted between RNAIII and sarT mRNA (Supplementary Table S1), a member of the transcriptional regulator of the sar family known to be negatively regulated by SarA and agr (Schmidt et al. 2003).

Such multiple levels of regulation of the genes encoding virulence factors are remarkable and suggest that timing and the amount of production of each of these virulence factors need to be precisely controlled during the course of infection. It also provides the bacteria with various ways to integrate several external signals. The fact that the conserved 3' domain "concentrates" a direct and an indirect control of expression of many virulence factors suggests that this part of the molecule has been subject to strong evolutionary constraints. In contrast, other parts of the RNAIII molecule are much more divergent, probably owing to species-specific traits. Further studies will be required to identify the complete RNAIII-dependent regulatory networks in staphylococcal strains. Elucidating the functions of the novel noncoding RNAs in $S$. aureus should also provide a clearer picture of the importance of RNA in biological processes of this pathogen.

\section{Materials and methods}

Strains and plasmids

S. aureus RN6390 derives from 8325-4. In WA400 (DrnaIII), the P3 operon is deleted and replaced by the chloramphenicol trans- 
acetylase gene (cat86) (Janzon and Arvidson 1990). LUG774 and LUG911 strains derive from RN6390 in which the RNase III (rnc) and $h f q$ genes, respectively, have been replaced by cat 86 gene (Huntzinger et al. 2005). The deletion/replacement $\Delta h f q /$ cat mutant of $S$. aureus RN6390 (LUG 911) was obtained by using pMAD, a thermosensitive plasmid (Arnaud et al. 2004). For experimental details, see the Supplemental Material. Clones were transferred by electroporation into RN4220, a nitrosoguanidine-induced mutant capable of accepting E. coli DNA, before transfer to other strains. Staphylococci were grown either on BM agar plates or in brain-heart infusion (BHI) with erythromycin $(5 \mu \mathrm{g} / \mathrm{mL})$ when appropriate. RNAIII and its variants were expressed in $S$. aureus WA400 by using plasmid pE194 (see Table 1).

\section{Construction of translation fusions and $\beta$-galactosidase measurements}

Translation fusions were constructed by using plasmid pLUG220, a derivative of pTCV-1ac, a low-copy-number promoter-less lacZ vector (Table 1). Leader regions of SA1000 and rot mRNAs were cloned downstream from the $r p o B$ promoter in frame with lacZ (Huntzinger et al. 2005). $\beta$-Galactosidase activity was measured three times on duplicate cultures with the Enzyme Assay System (Promega).

\section{Northern blots and measure of mRNA half-life}

Electrophoresis of total RNA, prepared from late exponential growth phase of different $S$. aureus strains, was done on a $1 \%$ agarose gel containing 2.2 M formaldehyde. Hybridizations were carried out with end-labeled-specific probes to detect mRNA, RNAIII, or 5S rRNA (Huntzinger et al. 2005).

\section{RNA preparation}

RNAIII, RNAIII derivatives (RNAIII- $\Delta 7-9$ deletion of nucleotides G207-U319, RNAIII- $\Delta 13$ deletion of nucleotides U409A451, and RNAIII- $\Delta 14$ deletion of nucleotides G483-C511); the isolated hairpins 7, 13, and 14; and mRNA fragments were transcribed in vitro using T7 RNA polymerase as previously described (Benito et al. 2000). Before use, RNAs were renatured by incubation for $2 \mathrm{~min}$ at $90^{\circ} \mathrm{C}$ in RNase-free water, $1 \mathrm{~min}$ at $4^{\circ} \mathrm{C}$, followed by an incubation step for $15 \mathrm{~min}$ at $20^{\circ} \mathrm{C}$ in TMN buffer $(20 \mathrm{mM}$ Tris-acetate at $\mathrm{pH}$ 7.5, $10 \mathrm{mM}$ magnesium-acetate, $150 \mathrm{mM} \mathrm{Na}$-acetate).

\section{RNA structure probing and toeprinting assays}

Enzymatic hydrolysis, chemical modifications, and RNase III hydrolysis on free or bound RNAs were performed as previously described (Huntzinger et al. 2005). The formation of a simplified translational initiation complex with mRNA and the extension inhibition conditions were strictly identical to those described by (Benito et al. 2000).

\section{In silico approach}

All 5' regions of mRNA of $S$. aureus N315 were extracted from the genomic sequence as a multifasta file including the following for each mRNA: $28 \mathrm{nt}$ before the start, the start, and $30 \mathrm{nt}$ after the start. Hybridization with the hairpin 13 (H13) domain of RNAIII was simulated by concatenating each 61-nt sequence with a spacer of $8 \mathrm{~N}$ and the $5^{\prime}$ region of $\mathrm{H} 13$ known to be involved in the interaction with spa mRNA. We used Zuker's algorithm of the version 1.5 of Vienna RNA package RNAfold (http://www.tbi.univie.ac.at/ ivo/RNA) to compute minimum free energy of each sequence and to predict the secondary struc- ture of the target mRNAs. Only the best folds showing hybridization between $\mathrm{H} 13$ and the 5' region of the mRNA were considered as potential targets.

\section{Acknowledgments}

We are thankful to J.C. Cortay for helpful technical advice and for providing the modified pET43 vector, and to C. Guillier and C. Lichte for the analysis of the proteins by mass spectroscopy. We are grateful to G. Wagner, G. Lina, J. Etienne, and E. Westhof for helpful discussions, and to C. Isel and N. Grover for critical reading of the manuscript. This work was supported by the Centre National de la Recherche Scientifique (CNRS), the Institut National pour la Recherche Médicale (INSERM), the Agence Nationale pour la Recherche (ANR), the Ligue Régionale contre le Cancer, the Fondation pour la Recherche Médicale, and the European Community (FOSRAK, FP6-5120; BacRNA, FP6-018618). M.P. was supported by a fellowship from the Fondation pour la Recherche Médicale.

\section{References}

Argaman, L. and Altuvia, S. 2000. fhlA repression by OxyS RNA: Kissing complex formation at two sites results in a stable antisense-target RNA complex. J. Mol. Biol. 300: 1101-1112.

Arnaud, M., Chastanet, A., and Debarbouille, M. 2004. New vector for efficient allelic replacement in naturally nontransformable, low-GC-content, gram-positive bacteria. Appl. Environ. Microbiol. 70: 6887-6891.

Balaban, N. and Novick, R.P. 1995. Translation of RNAIII, the Staphylococcus aureus agr regulatory RNA molecule, can be activated by a $3^{\prime}$-end deletion. FEMS Microbiol. Lett. 133: $155-161$.

Benito, Y., Lina, G., Greenland, T., Etienne, J., and Vandenesch, F. 1998. Trans-complementation of a Staphylococcus aureus agr mutant by Staphylococcus lugdunensis agr RNAIII. I. Bacteriol. 180: 5780-5783.

Benito, Y., Kolb, F.A., Romby, P., Lina, G., Etienne, J., and Vandenesch, F. 2000. Probing the structure of RNAIII, the Staphylococcus aureus agr regulatory RNA, and identification of the RNA domain involved in repression of protein A expression. RNA 6: 668-679.

Bohn, C., Rigoulay, C., and Bouloc, P. 2007. No detectable effect of RNA-binding protein Hfq absence in Staphylococcus aureus. BMC Microbiol. 7: 10.

Chang, B., Halgamuge, S., and Tang, S.-L. 2006. Analysis of SD sequences in completed microbial genomes: Non-SD-led genes are as common as SD-led genes. Gene 373: 90-99.

Cheung, A.L., Eberhardt, K.J., Chung, E., Yeaman, M.R., Sullam, P.M., Ramos, M., and Bayer, A.S. 1994. Diminished virulence of a sar-/agr- mutant of Staphylococcus aureus in the rabbit model of endocarditis. J. Clin. Invest. 94: 1815-1822.

Cordwell, S.J., Larsen, M.R., Cole, R.T., and Walsh, B.J. 2002. Comparative proteomics of Staphylococcus aureus and the response of methicillin-resistant and methicillin-sensitive strains to Triton X-100. Microbiol. 148: 2765-2781.

Dubrac, S. and Msadek, T. 2004. Identification of genes controlled by the essential YycG/YycF two-component system of Staphylococcus aureus. J. Bacteriol. 186: 1175-1181.

Dunman, P.M., Murphy, E., Haney, S., Palacios, D., TuckerKellogg, G., Wu, S., Brown, E.L., Zagursky, R.J., Shlaes, D., and Projan, S.J. 2001. Transcription profiling-based identification of Staphylococcus aureus genes regulated by the agr and/or sarA loci. J. Bacteriol. 183: 7341-7353.

Geisinger, E., Adhikari, R.P., Jin, R., Ross, H.F., and Novick, R.P. 2006. Inhibition of rot translation by RNAIII, a key 
feature of agr function. Mol. Microbiol. 61: 1038-1048.

Gillaspy, A.F., Hickmon, S.G., Skinner, R.A., Thomas, J.R., Nelson, C.L., and Smeltzer, M.S. 1995. Role of the accessory gene regulator $(a g r)$ in pathogenesis of staphylococcal osteomyelitis. Infect. Immun. 63: 3373-3380.

Gottesman, S. 2005. Micros for microbes: Non-coding regulatory RNAs in bacteria. Trends Genet. 21: 399-404.

Guillier, M., Gottesman, S., and Storz, G. 2006. Modulating the outer membrane with small RNAs. Genes \& Dev. 20: 23382348.

Horinouchi, S. and Weisblum, B. 1982. Nucleotide sequence and functional map of $\mathrm{pE194}$, a plasmid that specifies inducible resistance to macrolide, lincosamide, and streptogramin type B antibodies. J. Bacteriol. 150: 804-814.

Huntzinger, E., Boisset, S., Saveanu, C., Benito, Y., Geissmann, T., Namane, A., Lina, G., Etienne, J., Ehresmann, B., Ehresmann, C., et al. 2005. Staphylococcus aureus RNAIII and the endoribonuclease III coordinately regulate spa gene expression. $E M B O$ J. 24: 824-835.

Hussain, M., Becker, K., von Eiff, C., Schrenzel, J., Peters, G., and Herrmann, M. 2001. Identification and characterization of a novel 38.5-kilodalton cell surface protein of Staphylococcus aureus with extended-spectrum binding activity for extracellular matrix and plasma proteins. J. Bacteriol. 183: 6778-6786.

Janzon, L. and Arvidson, S. 1990. The role of the $\delta$-lysin gene (hld) in the regulation of virulence genes by the accessory gene regulator (agr) in Staphylococcus aureus. EMBO I. 9: 1391-1399.

Kreiswirth, B.N., Lofdahl, S., Betley, M.J., O'Reilly, M., Schlievert, P.M., Bergdoll, M.S., and Novick, R.P. 1983. The toxic shock syndrome exotoxin structural gene is not detectably transmitted by a prophage. Nature 305: 709-712.

Lang, S., Livesley, M.A., Lambert, P.A., Littler, W.A., and Elliott, T.S. 2000. Identification of a novel antigen from Staphylococcus epidermidis. FEMS Immunol. Med. Microbiol. 29: 213-220.

Lebeau, C., Vandenesch, F., Greenland, T., Novick, R.P., and Etienne, J. 1994. Coagulase expression in Staphylococcus aureus is positively and negatively modulated by an agrdependent mechanism. J. Bacteriol. 176: 5534-5536.

Liang, X., Zheng, L., Landwehr, C., Lunsford, D., Holmes, D., and Ji, Y. 2005. Global regulation of gene expression by ArlRS, a two-component signal transduction regulatory system of Staphylococcus aureus. J. Bacteriol. 187: 5486-5492.

Liang, X., Yu, C., Sun, J., Liu, H., Landwehr, C., Holmes, D., and Ji, Y. 2006. Inactivation of a two-component signal transduction system, SaeRS, eliminates adherence and attenuates virulence of Staphylococcus aureus. Infect. Immun. 74: 4655-4665.

Luong, T.T., Dunman, P.M., Murphy, E., Projan, S.J., and Lee, C.Y. 2006. Transcription profiling of the mgra regulon in Staphylococcus aureus. J. Bacteriol. 188: 1899-1910.

Mandin, P., Repoila, F., Vergassola, M., Geissmann, T., and Cossart, P. 2007. Identification of new noncoding RNAs in Listeria monocytogenes and prediction of mRNA targets. Nucleic Acids Res. 35: 962-974.

Morfeldt, E., Taylor, D., von Gabain, A., and Arvidson, S. 1995. Activation of $\alpha$-toxin translation in Staphylococcus aureus by the trans-encoded antisense RNA, RNAIII. EMBO J. 14: 4569-4577.

Morita, T., Maki, K., and Aiba, H. 2005. RNase E-based ribonucleoprotein complexes: Mechanical basis of mRNA destabilization mediated by bacterial noncoding RNAs. Genes \& Dev. 19: 2176-2186.

Morita, T., Mochizuki, Y., and Aiba, H. 2006. Translational repression is sufficient for gene silencing by bacterial small noncoding RNAs in the absence of mRNA destruction. Proc. Natl. Acad. Sci. 103: 4858-4863.

Novick, R.P. 2003. Autoinduction and signal transduction in the regulation of staphylococcal virulence. Mol. Microbiol. 48: 1429-1449.

Novick, R.P., Ross, H.F., Projan, S.J., Kornblum, J., Kreiswirth, B., and Moghazeh, S. 1993. Synthesis of staphylococcal virulence factors is controlled by a regulatory RNA molecule. EMBO J. 12: 3967-3975.

Oscarsson, J., Harlos, C., and Arvidson, S. 2005. Regulatory role of proteins binding to the spa (protein A) and sarS (staphylococcal accessory regulator) promoter regions in Staphylococcus aureus NTCC 8325-4. Int. J. Med. Microbiol. 295: 253-266.

Oscarsson, J., Tegmark-Wisell, K., and Arvidson, S. 2006. Coordinated and differential control of aureolysin (aur) and serine protease $(\operatorname{ssp} A)$ transcription in Staphylococcus aureus by sarA, rot and agr (RNAIII). Int. J. Med. Microbiol. 296: 365-380.

Peng, H.L., Novick, R.P., Kreiswirth, B., Kornblum, J., and Schlievert, P. 1988. Cloning, characterization, and sequencing of an accessory gene regulator $(a g r)$ in Staphylococcus aureus. J. Bacteriol. 170: 4365-4372.

Pichon, C. and Felden, B. 2005. Small RNA genes expressed from Staphylococcus aureus genomic and pathogenicity islands with specific expression among pathogenic strains. Proc. Natl. Acad. Sci. 102: 14249-14254.

Poyart, C. and Trieu-Cuot, P. 1997. A broad-host-range mobilizable shuttle vector for the construction of transcriptional fusions to $\beta$-galactosidase in Gram-positive bacteria. FEMS Microbiol. Lett. 156: 193-198.

Ramadurai, L., Lockwood, K.J., Nadakavukaren, M.J., and Jayaswal, R.K. 1999. Characterization of a chromosomally encoded glycylglycine endopeptidase of Staphylococcus aureus. Microbiol. 145: 801-808.

Roberts, C., Anderson, K.L., Murphy, E., Projan, S.J., Mounts, W., Hurlburt, B., Smeltzer, M., Overbeek, R., Disz, T., and Dunman, P.M. 2006. Characterizing the effect of the Staphylococcus aureus virulence factor regulator, SarA, on logphase mRNA half-lives. J. Bacteriol. 188: 2593-2603.

Said-Salim, B., Dunman, P.M., McAleese, F.M., Macapagal, D., Murphy, E., McNamara, P.J., Arvidson, S., Foster, T.J., Projan, S.J., and Kreiswirth, B.N. 2003. Global regulation of Staphylococcus aureus genes by Rot. J. Bacteriol. 185: 610-619.

Schmidt, K.A., Manna, A.C., and Cheung, A.L. 2003. SarT influences sarS expression in Staphylococcus aureus. Infect. Immun. 71: 5139-5148.

Sibbald, M.J., Ziebandt, A.K., Engelmann, S., Hecker, M., de Jong, A., Harmsen, H.J., Raangs, G.C., Stokroos, I., Arends, J.P., Dubois, J.Y., et al. 2006. Mapping the pathways to staphylococcal pathogenesis by comparative secretomics. Microbiol. Mol. Biol. Rev. 70: 755-788.

Storz, G., Altuvia, S., and Wassarman, K.M. 2005. An abundance of RNA regulators. Annu. Rev. Biochem. 74: 199-217.

Valentin-Hansen, P., Eriksen, M., and Udesen, C. 2004. The bacterial Sm-like protein Hfq: A key player in RNA transactions. Mol. Microbiol. 51: 1525-1533.

Vandenesch, F., Kornblum, J., and Novick, R.P. 1991. A temporal signal, independent of $a g r$, is required for hla but not spa transcription in Staphylococcus aureus. J. Bacteriol. 173: 63136320.

Vogel, J. and Papenfort, K. 2006. Small non-coding RNAs and the bacterial outer membrane. Curr. Opin. Microbiol. 9: 605-611.

Wagner, E.G.H., Altuvia, S., and Romby, P. 2002. Antisense RNAs in bacteria and their genetic elements. Adv. Genet. 46: 361-398. 


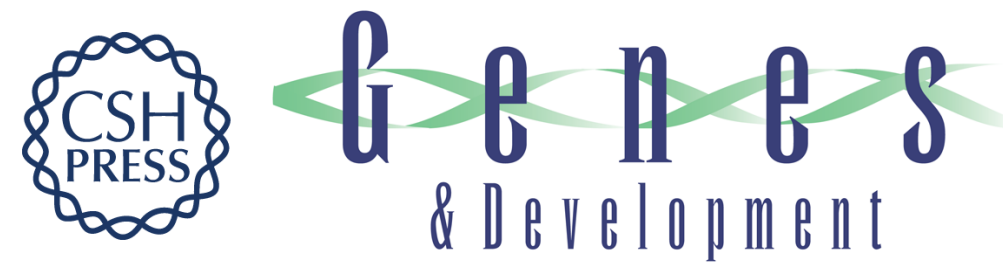

\section{Staphylococcus aureus RNAIII coordinately represses the synthesis of virulence factors and the transcription regulator Rot by an antisense mechanism}

Sandrine Boisset, Thomas Geissmann, Eric Huntzinger, et al.

Genes Dev. 2007, 21:

Access the most recent version at doi:10.1101/gad.423507

Supplemental http://genesdev.cshlp.org/content/suppl/2007/05/18/21.11.1353.DC1

Material

References This article cites 46 articles, 23 of which can be accessed free at:

http://genesdev.cshlp.org/content/21/11/1353.full.html\#ref-list-1

License

Email Alerting Receive free email alerts when new articles cite this article - sign up in the box at the top

Service right corner of the article or click here.

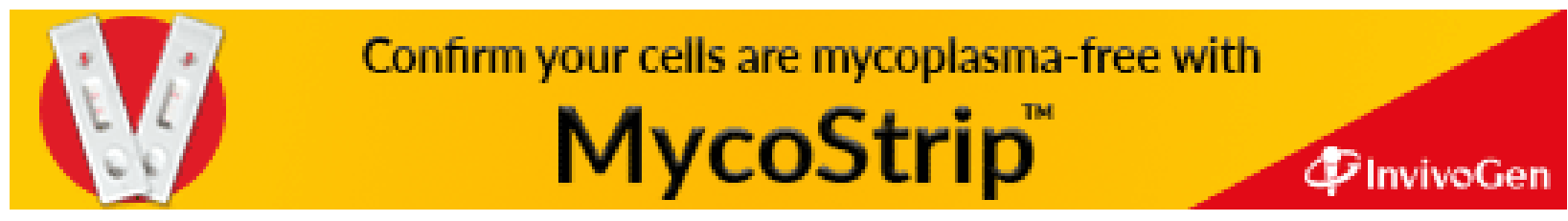

